\title{
Concentrations of Heavy Metal Cations and a Health Risk Assessment of Sediments and River Surface Water: A Case Study from a Serbian Mine
}

\author{
Nenad Živković1*, Ljiljana Takić², Ljiljana Djordjević ${ }^{3}$, Amelija Djordjević1, \\ Ivana Mladenović-Ranisavljević , Tatjana Golubović ${ }^{1}$, Aca Božilov ${ }^{1}$ \\ ${ }^{1}$ University of Niš, Faculty of Occupational Safety, Department of Environmental Engineering, Niš, Serbia \\ ${ }^{2}$ University of Niš, Faculty of Technology, Department of Chemical Engineering, Nišs, Serbia \\ ${ }^{3}$ College of Applied Studies, Department of Environmental Chemistry, Vranje, Serbia
}

Received: 23 December 2017

Accepted: 16 April 2018

\begin{abstract}
Mining and processing of metal ores are often significant sources of heavy metal contamination of river sediments. Heavy metal contamination of river sediments resulting from mining and smelting represents a major concern due to the potential risk involved. This study was performed to investigate the content of heavy metal $(\mathrm{Cd}, \mathrm{Cr}, \mathrm{Fe}, \mathrm{Mn}, \mathrm{Ni}, \mathrm{Cu}, \mathrm{Pb}, \mathrm{Hg}$, As, and $\mathrm{Ba}$ ) cations in the sediments of the Korbevačka River, the main recipient of all kinds of pollutants from the $\mathrm{Pb}-\mathrm{Zn}$ Grot Mine, and to estimate the potential health risks of metals to humans. On the basis of the heavy metal cations content, the potential health risk assessment calculated for a lifetime of exposure (ingestion and inhalation), based on the U.S. Environmental Protection Agency (EPA) model, was determined as the cumulative noncarcinogenic and carcinogenic risk for children and adults. The study proved that: a) the heavy metal cations content in the Korbevačka River sediments is significant; b) risk assessment indicates that while carcinogenic risk is completely insignificant, cumulative non-carcinogenic risk is significant - especially for children - as it approaches unacceptable values; and c) metal lead is the main concern in regard to negative influence on human health.
\end{abstract}

Keywords: health risk assessment, human exposure, heavy metal cations, sediments

\section{Introduction}

Anthropogenic activities like mining, the disposal of treated/untreated waste effluents containing toxic metals, and metal chelates from different industries and the indiscriminate use of heavy metals containing fertilizers and pesticides in agriculture deteriorate water quality by rendering serious environmental problems posing a threat to human health $[1,2]$ and aquatic biodiversity $[3,4]$.

*e-mail: nenad.zivkovic@znrfak.ni.ac.rs 
The behavior of metal cations in natural waters is a function of the substrate sediment composition, suspended sediment composition, and water chemistry. During their transport, heavy metal cations undergo numerous changes in their speciation due to dissolution, precipitation, sorption, and complexation phenomena [5], which affect their behavior and bioavailability $[6,7]$. Metal cations entering the ecosystem may lead to geoaccumulation, bioaccumulation, and biomagnification, and may have possibilities for environmental transformation into more toxic forms. When entered into an aquatic environment, these toxic heavy metal cations are adsorbed onto particulate matter, although they can form free metal ions and soluble complexes that are available for uptake by biological organisms, or get deposited in sediments [8].

In hydrosphere, the concentrations of toxic metal cations are significantly greater in sediments than in overlying waters. In this way, superficial sediments, particularly the fine fraction, accumulate cations of toxic heavy metals and provide a means for evaluating the long-term accumulation of these metal contaminants [9]. The capacity of sediments to concentrate trace levels of metal cations is a useful indicator for monitoring purposes and for detecting the sources of pollution in the aquatic system. Monitoring of these toxic heavy metals is important for environmental safety assessment and especially for human health [10-14].
The purpose of our investigation of the Korbevačka River sediments was to define the level of pollution of the river sediments, based on Canadian sediment quality guidelines [15], and to determine their potential health risk as a cumulative carcinogenic and non-carcinogenic risk for children and adults. Health risk assessment of heavy metals pollution in Korbevačka sediments has not yet been done, so the results of this investigation are mostly required for the purpose of environmental and health protection.

\section{Materials and Methods}

The Korbevačka, with a river basin of $76.72 \mathrm{~km}^{2}$, is a right-side tributary of the South Morava River in southeastern Serbia (Fig. 1).

The river's upper and middle flow belong to a mountainous region, while the lower flow belongs to Vranje Depression, where the flow amplitudes are quite high and the annual river deposit exceeds $107000 \mathrm{~m}^{3}$. The Korbevačka is a main recipient of all kinds of pollutants from the $\mathrm{Pb}-\mathrm{Zn}$ Grot Mine. The river has a $\mathrm{pH}$ value near neutral to slightly alkaline, which is the usual range in river waters. The values for other physicochemical parameters of river water such as electrical conductivity, total dissolved solids, and suspended matter are within the range typical of category A2, and

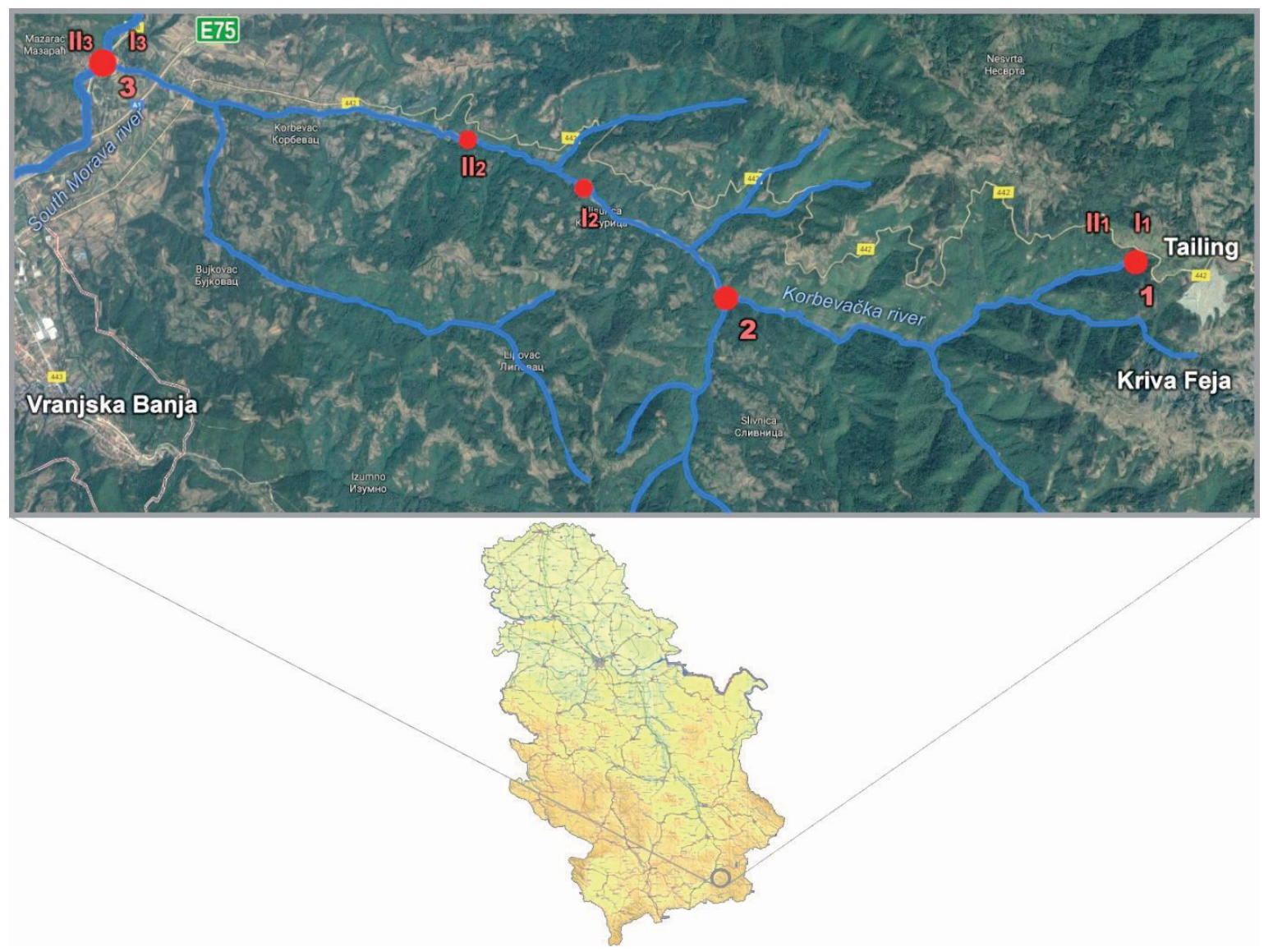

Fig. 1. Locations of sediment sampling. 
Table 1. Mean concentrations of heavy metal cations in Korbevačka River sediments.

\begin{tabular}{|c|c|c|c|c|c|c|c|c|c|c|}
\hline Sample & $\begin{array}{c}\mathrm{Fe} \\
(\mathrm{mg} / \mathrm{kg})\end{array}$ & $\begin{array}{c}\mathrm{Mn} \\
(\mathrm{mg} / \mathrm{kg})\end{array}$ & $\begin{array}{c}\mathrm{Cr} \\
(\mathrm{mg} / \mathrm{kg})\end{array}$ & $\begin{array}{c}\mathrm{Ni} \\
(\mathrm{mg} / \mathrm{kg})\end{array}$ & $\begin{array}{c}\mathrm{Cu} \\
(\mathrm{mg} / \mathrm{kg})\end{array}$ & $\begin{array}{c}\mathrm{Pb} \\
(\mathrm{mg} / \mathrm{kg})\end{array}$ & $\underset{(\mu \mathrm{g} / \mathrm{kg})}{\mathrm{Hg}}$ & $\begin{array}{c}\mathrm{Cd} \\
(\mathrm{mg} / \mathrm{kg})\end{array}$ & $\begin{array}{c}\mathrm{As} \\
(\mu \mathrm{g} / \mathrm{kg})\end{array}$ & $\begin{array}{c}\mathrm{Ba} \\
(\mathrm{mg} / \mathrm{kg})\end{array}$ \\
\hline \multicolumn{11}{|c|}{ The Korbevačka River, the upper part of the river basin - sampling location No 1.} \\
\hline $\mathrm{I}_{1}$ & 26070.4 & 6035.6 & 25.2 & 40.4 & 859.9 & 4340.0 & 60.0 & 13.9 & 238.6 & 32.3 \\
\hline $\mathrm{II}_{1}$ & 32244.8 & 5419.8 & 34.9 & 25.8 & 375.9 & 7620.7 & 35.7 & 7.9 & 229.2 & 28.4 \\
\hline \multicolumn{11}{|c|}{ The Korbevačka River, the middle part of the river basin - sampling location No 2 . } \\
\hline $\mathrm{I}_{2}$ & 8565.6 & 1187.5 & 8.5 & 8.7 & 60.9 & 621.7 & 4.2 & 1.7 & 234.3 & 33.2 \\
\hline $\mathrm{II}_{2}$ & 11506.1 & 1396.9 & 10.7 & 11.8 & 85.7 & 862.9 & 1.4 & 3.9 & 258.2 & 24.4 \\
\hline \multicolumn{11}{|c|}{ The Korbevačka River, the lower part of the river basin - sampling location No 3 . } \\
\hline $\mathrm{I}_{3}$ & 9449.3 & 684.3 & 10.5 & 10.7 & 48.9 & 596.8 & 8.0 & 2.2 & 230.3 & 47.7 \\
\hline $\mathrm{II}_{3}$ & 12297.0 & 1157.1 & 15.4 & 13.4 & 84.9 & 719.4 & 5.5 & 3.7 & 229.5 & 69.9 \\
\hline \multicolumn{11}{|c|}{ Interim fresh water sediment quality guidelines. ISQG- Canadian sediment quality guidelines. 2002.} \\
\hline ISQG & & & 37.3 & & 35.7 & 35.0 & 170.0 & 0.6 & 5900 & \\
\hline
\end{tabular}

the value for dissolved oxygen is within the category A1 range, as given by Council Directive 75/440/EEC $[16,17]$.

Our study was based on monitoring the sediment chemical composition. Sediment samples of the Korbevačka were taken from carefully selected locations along this river (Fig. 1). The sampling locations included areas near the mine and domestic effluent discharge points, agricultural dewatering areas, and places of tourism activities. Sampling was performed during both the minimum (September) and the maximum (April) water level periods. Contamination risk assessment was performed in accordance with mean concentration values of these two periods [18].

The river sediment samples were collected from three locations: the tailing of the Grot Mine - the upper flow (1); the confluence of the Korbevačka with its tributary Seleš Stream - the middle flow (2); and the confluence of the Korbevačka with the South Morava River - the lower flow (3). Samples $\mathrm{I}_{1}$ and $\mathrm{II}_{1}$ were taken from sampling location (1), samples $\mathrm{I}_{2}$ and $\mathrm{II}_{2}$ were taken in the region of sampling location (2) below the mouth of Seleš Stream, and samples $\mathrm{I}_{3}$ and $\mathrm{II}_{3}$ were taken from sampling location (3). All the samples were taken from the locations where the river flow was peaceful, from 0-10 cm layer surface sediments.

The samples were prepared in the laboratory. Flame atomic absorption spectrometry was used to determine the concentrations of metal cations. All the results of the sediment analysis are expressed as $\mathrm{mg} / \mathrm{kg}$ (or as $\mu \mathrm{g} / \mathrm{kg}$ ) dry matter.

All the samples were repeatedly measured $(n=3)$ to control the precision of analytical instruments. Analytical precision was less than 5\% for all metals. The efficiency of the digestion procedure and analytical quality were controlled by the use of the standard reference material GBW07411 (soil) and sample duplicates. The values of heavy metal cations concentrations were as follows (mean $\pm \mathrm{SD}$ in $\mathrm{mg} / \mathrm{kg}$ ):

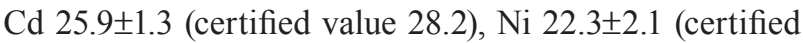
value 24.2), $\mathrm{Cu} 62.9 \pm 4.7$ (certified value 65.4), $\mathrm{Pb}$ $3010 \pm 100$ (certified value 2700), Cr 57.5 \pm 5.0 (certified value 59.6), and As 193 \pm 11 (certified value 205). The recovery rates for metal cations in the standard reference material were between 91.8 and $111.5 \%$.

In the present study, heavy metal $(\mathrm{Cd}, \mathrm{Cr}, \mathrm{Fe}, \mathrm{Mn}$, $\mathrm{Ni}, \mathrm{Cu}, \mathrm{Pb}, \mathrm{Hg}, \mathrm{As}$, and $\mathrm{Ba}$ ) cations have been identified as potential hazardous agents relevant to human health in the sediments at different locations along the Korbevačka (Table 1).

The relationship between the intensity of the environmental pollution and the potential risk to human health can be assessed by human health risk assessment methodology proposed by the U.S. EPA [19]. This methodology has been developed in detail. It is fully available through a risk assessment information system (RAIS) [20] and is supported by the toxicological profiles developed and gathered by the U.S. EPA Integrated Risk Information System (IRIS) [21], and by the U.S. Agency for Toxic Substances and Disease Registry - Toxicological profiles (ATSDR) [22]. Some toxicological characteristics of the investigated elements are shown in Table 2.

Exposure is expressed in terms of a chronic daily intake or dose, CDI, and is calculated separately for each metal, for children and adults, and exposure by ingestion and inhalation. Dermal exposure to sediment was omitted in this specific case as these risks are about 100 times smaller than the risks that arise from ingestion and inhalation.

Specifically, the chronic daily intake through ingestion and inhalation of river sediment particles was calculated as shown in Equations (1) and (2), adapted from [23]. For mercury, the only element of those included in the study with a significant vapour pressure at ambient temperatures, an additional route 
Table 2. Some toxicological characteristics of the investigated elements.

\begin{tabular}{|c|c|c|c|c|c|c|c|c|c|c|}
\hline Characteristic & $\mathrm{Mn}$ & $\mathrm{Ni}$ & $\mathrm{Cr}$ & $\mathrm{Cd}$ & $\mathrm{Pb}$ & $\mathrm{Cu}$ & $\mathrm{Hg}$ & As & $\mathrm{Ba}$ & $\mathbf{F e}$ \\
\hline $\begin{array}{l}\text { Minimal risk level (MRL) oral } \\
\left(\mathrm{mg} / \mathrm{m}^{3} \cdot \text { day }\right)\end{array}$ & & & 0.005 & 0.0001 & & 0.01 & 0.0002 & 0.0003 & 0.2 & \\
\hline $\begin{array}{l}\text { Minimal risk level (MRL) } \\
\text { inhalation }\left(\mathrm{mg} / \mathrm{m}^{3} \cdot \text { day }\right)\end{array}$ & 0.00003 & 0.00009 & 0.0003 & 0.00001 & & & & & & \\
\hline $\begin{array}{l}\text { RAIS oral chronic reference dose, } \\
\mathrm{RfD}(\mathrm{mg} / \mathrm{kg} / \text { day })\end{array}$ & $4.6 \cdot 10^{-2}$ & $2 \cdot 10^{-2}$ & $3 \cdot 10^{-3}$ & $1 \cdot 10^{-3}$ & $3.5 \cdot 10^{-3}$ & $4 \cdot 10^{-2}$ & $3 \cdot 10^{-4}$ & $3 \cdot 10^{-4}$ & $7 \cdot 10^{-2}$ & 0.7 \\
\hline $\begin{array}{c}\text { RAIS inhalation chronic reference } \\
\text { dose, RfD } \\
\left(\mathrm{mg} / \mathrm{m}^{3} \cdot \text { day }\right)\end{array}$ & $\begin{array}{c}1.43 \cdot 10^{-} \\
5\end{array}$ & $\begin{array}{c}1.43 \cdot 10^{-} \\
5\end{array}$ & $2.86 \cdot 10^{-5}$ & $5.7 \cdot 10^{-6}$ & & $4 \cdot 10^{-2}$ & $8.57 \cdot 10^{-5}$ & & $1.43 \cdot 10^{-4}$ & \\
\hline $\begin{array}{c}\text { Slope factor, SF oral }(\mathrm{mg} / \mathrm{kg} / \text { day }) \\
\text { inhalation }\left(\mathrm{mg} / \mathrm{m}^{3} \cdot \text { day }\right)\end{array}$ & & $8.4 \cdot 10^{-1}$ & $4.2 \cdot 10^{1}$ & 6.3 & & & & $\begin{array}{c}1.5 \\
1.51 \cdot 10^{1}\end{array}$ & & \\
\hline $\begin{array}{c}\text { Cancer EPA weight-of-evidence } \\
\text { classification }^{\mathrm{b}}\end{array}$ & B2 & B2 & $\begin{array}{l}\mathrm{Cr}(\mathrm{VI}) \mathrm{A} \\
\mathrm{Cr}(\mathrm{III}) \mathrm{D}\end{array}$ & B1 & B2 & $\mathrm{D}$ & $\mathrm{D}$ & A & $\mathrm{D}$ & $\mathrm{C}$ \\
\hline Inhalation Unit Risk $\left(\mathrm{mg} / \mathrm{m}^{3}\right)^{\mathrm{c}}$ & & $8.4 \cdot 10^{-1}$ & $1.5 \cdot 10^{-1}$ & $4.2 \cdot 10^{-3}$ & $1.2 \cdot 10^{-5}$ & & & $4.3 \cdot 10^{-3}$ & & \\
\hline
\end{tabular}

a) Minimal risk level (MRL): an estimate of the daily human exposure to a hazardous substance that is likely to be without an appreciable risk of adverse non-cancer health effects over a specified route and duration of exposure

b) Cancer EPA weight-of-evidence classification: A - human carcinogen, B1 - probable human carcinogen, B2 - probable human carcinogen, $\mathrm{C}$ - possible human carcinogen, D - not classifiable as to human carcinogenicity, E - good evidence for absence of carcinogenicity

c) Unit risk: excess lifetime cancer risk per unit concentration of the substance in the medium where human contact occurs $\left(1 \mu \mathrm{g} / \mathrm{L}\right.$ in water or $1 \mu \mathrm{g} / \mathrm{m}^{3}$ in air), usually expressed in units of proportion (of a population)

of exposure, i.e., inhalation of vapours, was considered, Equation (3).

Chronic daily intake through ingestion of river sediment particles:

$$
C D I_{i n g}(\mathrm{mg} / \mathrm{kg} \cdot \text { day })=\frac{C S \cdot I R \cdot E F \cdot E D}{B W \cdot A T}
$$

Chronic daily intake through inhalation of river sediment particles:

$$
C D I_{i n h}(\mathrm{mg} / \mathrm{kg} \cdot \text { day })=\frac{C S \cdot I N \cdot E F \cdot E D}{P E F \cdot B W \cdot A T}
$$

Dose contacted through inhalation of vapours (for mercury only):

$$
C D I_{\text {vapour }}(\mathrm{mg} / \mathrm{kg} \cdot \mathrm{day})=\frac{\mathrm{CS} \cdot \mathrm{IN} \cdot E F \cdot E D}{\mathrm{~V} F \cdot B W \cdot A T}
$$

... where CS $(\mathrm{mg} / \mathrm{kg})$ is the concentration of metal cations in river sediments ("exposure point concentration"); IR is the ingestion rate $(0.0002 \mathrm{~kg} /$ day for child and $0.0001 \mathrm{~kg} /$ day for adult); IN is inhalation rate (the most recent EPA guidance recommends daily rates of $10 \mathrm{~m}^{3} /$ day for child and $20 \mathrm{~m}^{3} /$ day for adult); $\mathrm{EF}$ is the exposure frequency (350 day/year); ED is the exposure duration (6 years for child and 24 years, for general case 30 years, for adult); PEF is the particle emission factor, climate specific $\left(1.36 \cdot 10^{9} \mathrm{~m}^{3} / \mathrm{kg}\right)$; BW is the average body weight (15 kg for child and $70 \mathrm{~kg}$ for adult); AT is the average time (365 day/year - ED for non-carcinogens and 365 day/year .70 year for carcinogens); and VF is the volatilization factor (for element $\mathrm{Hg} 32675.6 \mathrm{~m}^{3} / \mathrm{kg}$ ) [24].

The lifetime average daily dose for carcinogens (LADD) used in the assessment of cancer risk has been calculated as a weighted average for each exposure route as shown in Eq. (4).

Calculating the lifetime average daily dose for carcinogens:

$L A D D(\mathrm{mg} / \mathrm{kg} \cdot$ day $)=\frac{C S \cdot E F}{A T} \cdot\left(\frac{C R_{\text {child }} \cdot E D_{\text {child }}}{B W_{\text {child }}}+\frac{C R_{\text {adult }} \cdot E D_{\text {adult }}}{B W_{\text {adult }}}\right)$

...where all the acronyms denote the same variables as in Equations (1)-(4), except: CR is the contact (or absorption) rate (i.e., ingestion $[\mathrm{CR}=\mathrm{IR}]$ and inhalation adsorption $[\mathrm{CR}=\mathrm{IN}]$ ).

Risk characterization relevant for the present investigation comprises calculations of carcinogenic and non-carcinogenic risks for ingestion and inhalation of sediments. The chronic daily intakes calculated for each element and exposure pathway are subsequently divided by the corresponding reference dose to yield a hazard quotient (HQ) (or non-cancer risk), whereas for carcinogens the dose is multiplied by the corresponding slope factor to produce a level of cancer risk (Risk).

The basic equation for calculating systemic toxicity or non-carcinogenic hazard for a single substance/ element is expressed as the hazard quotient:

$$
H Q=C D I / R f D
$$


...where the non-cancer hazard quotient is a unitless number that is not expressed as the probability of an individual suffering an adverse effect. As a rule, the greater the value of CDI/RfD above unity, the greater the level of concern, as CDI is greater than RfD. It is also the ratio of a single substance exposure level over a specified time period to a reference dose for that substance derived from a similar exposure period. CDI is the chronic daily intake of a toxicant expressed in $\mathrm{mg} / \mathrm{kg} \cdot \mathrm{day}$, and RfD is the chronic reference dose for the toxicant expressed in $\mathrm{mg} / \mathrm{kg} \cdot$ day. It is the $\mathrm{mg} / \mathrm{kg} \cdot$ day of the daily exposure level for the human population, including sensitive subpopulations, that is unlikely to be an appreciable risk of deleterious effects during a lifetime.

For carcinogens, the risks are estimated as the incremental probability of an individual developing cancer over a lifetime as a result of exposure to the potential carcinogen. The basic equation for calculating the excess lifetime cancer risk is:

$$
\text { Risk }=C D I \times S F
$$

...where "Risk" is a unitless probability of an individual developing cancer over a lifetime, CDI is the chronic daily intake $(\mathrm{mg} / \mathrm{kg} \cdot$ day); while $\mathrm{SF}$ is the slope factor, expressed in $\mathrm{mg} / \mathrm{kg} \cdot$ day. It converts the estimated daily intake averaged over a lifetime of exposure directly to incremental risk of an individual developing cancer.

As all risks are cumulative, it is possible to calculate the cumulative non-carcinogenic hazard expressed as the hazard index (HI) or cancer risk expressed as the total cancer risk (TCR).

For each chronic non-carcinogenic exposure, the separate chronic hazard index should be initially calculated from the ratios of the chronic daily intake (CDI) to the chronic reference dose (RfD) for the individual chemicals, and then the obtained results summarized as described in the equation:

$$
H I=\Sigma C D I_{k} / R f D_{k}
$$

...where hazard index (HI) is a unitless number that is not expressed as the probability of an individual suffering an adverse effect. As a rule, the greater the value of $\mathrm{CDI} / \mathrm{RfD}$ above unity, the higher the level of concern. It is the sum of more than one hazard quotient for multiple substances and/or multiple exposure pathways, $\mathrm{CDI}_{\mathrm{k}}$ is the chronic daily intake of the $\mathrm{k}^{\text {th }}$ toxicant in $\mathrm{mg} / \mathrm{kg} /$ day and $\mathrm{RfD}_{\mathrm{k}}$ is the chronic reference dose for the $\mathrm{k}^{\text {th }}$ toxicant in $\mathrm{mg} / \mathrm{kg} /$ day.

The cancer risk equation that describes estimates of incremental individual lifetime cancer risk for the simultaneous exposure to several carcinogens is:

$$
T C R=\Sigma C D I_{k} \times S F_{k}
$$

...where TCR is total cancer risk; $\mathrm{CDI}_{\mathrm{k}}$ is the chronic daily intake or dose (mg/kg-day) for substance $\mathrm{k}$; $\mathrm{SF}_{\mathrm{k}}$ is the slope factor, expressed in $(\mathrm{mg} / \mathrm{kg} \cdot \mathrm{day})^{-1}$, for substance $k$; and $\mathrm{CDI}_{\mathrm{k}} \times \mathrm{SF}_{\mathrm{k}}$ is the risk estimate for the $\mathrm{k}^{\text {th }}$ substance.

By incorporating the obtained measured data into the equations described above, the values for the noncarcinogenic hazard index and the carcinogenic lifetime risk for individual elements, the cumulative risk for different exposure pathways for individual elements and the cumulative risk for all elements were obtained (Table 3).

\section{Results and Discussion}

The metal cations content in the river sediments at the three studied locations (Fig. 1), in form of the mean concentrations for the minimum and maximum water level periods, is presented in Table 1. In the present study, no significant differences were found in sediment metal cation concentrations over these two periods.

The Korbevačka River is strongly influenced by the $\mathrm{Pb}-\mathrm{Zn}$ Grot Mine. Table 1 indicates that $\mathrm{Cu}, \mathrm{Pb}$, and $\mathrm{Cd}$ contents were much higher than those specified within Canadian sediment quality guidelines (ISQG). $\mathrm{Hg}, \mathrm{As}$, and $\mathrm{Cr}$ are below the guideline concentrations for river sediments, while $\mathrm{Fe}, \mathrm{Mn}, \mathrm{Ni}$, and $\mathrm{Ba}$ border values have not been defined within Canadian sediment quality guidelines. Along the river's flow, heavy metal $(\mathrm{Cu}, \mathrm{Pb}$, and $\mathrm{Cd}$ ) cations, which have concentrations much higher than specified in the guidelines document, originate directly from the mine and the flotation dump. The mine impact on the Korbevačka River is reflected in the much higher concentrations of $\mathrm{Fe}, \mathrm{Mn}, \mathrm{Ni}, \mathrm{Cr}$, and $\mathrm{Hg}$ cations in the sediments from the upper part of the river basin in comparison with their concentrations in the sediments from the middle and lower parts of the river basin. Concentrations of $\mathrm{Cr}$ and $\mathrm{Hg}$ cations were much lower than those in Canadian sediment quality guidelines [25], while Fe, Mn, and Ni border values have not been defined with the same guidelines (Table 1). The highest values of metal cations content (except for As and $\mathrm{Ba}$ ) were recorded in the vicinity of the mine (location 1), but downstream metal cations migration is clearly evident along the Korbevačka River (Table 1). There is a decrease in the concentration of all metal cations (except for $\mathrm{As}$ and $\mathrm{Ba}$ ) in the middle and the lower parts of the river compared to the higher part, which confirmed the reduced anthropogenic activities from the upper part to the middle and the lower parts of the river basin. The concentration of As is uniform and is much lower than the one in Canadian sediment quality guidelines, while the concentration of $\mathrm{Ba}$ increases along the river (Ba border value has not been defined within Canadian sediment quality guidelines). These metal cations (As and $\mathrm{Ba}$ ) can indicate their native origin in the Korbevačka River sediments. Middle and lower parts of the Korbevačka River catchment are mainly agricultural with a small village served by a small wastewater 
Table 3. Non-carcinogenic hazard index and carcinogenic lifetime risk for individual elements, cumulative risk for different exposure pathways for individual elements, and cumulative risk for all elements.

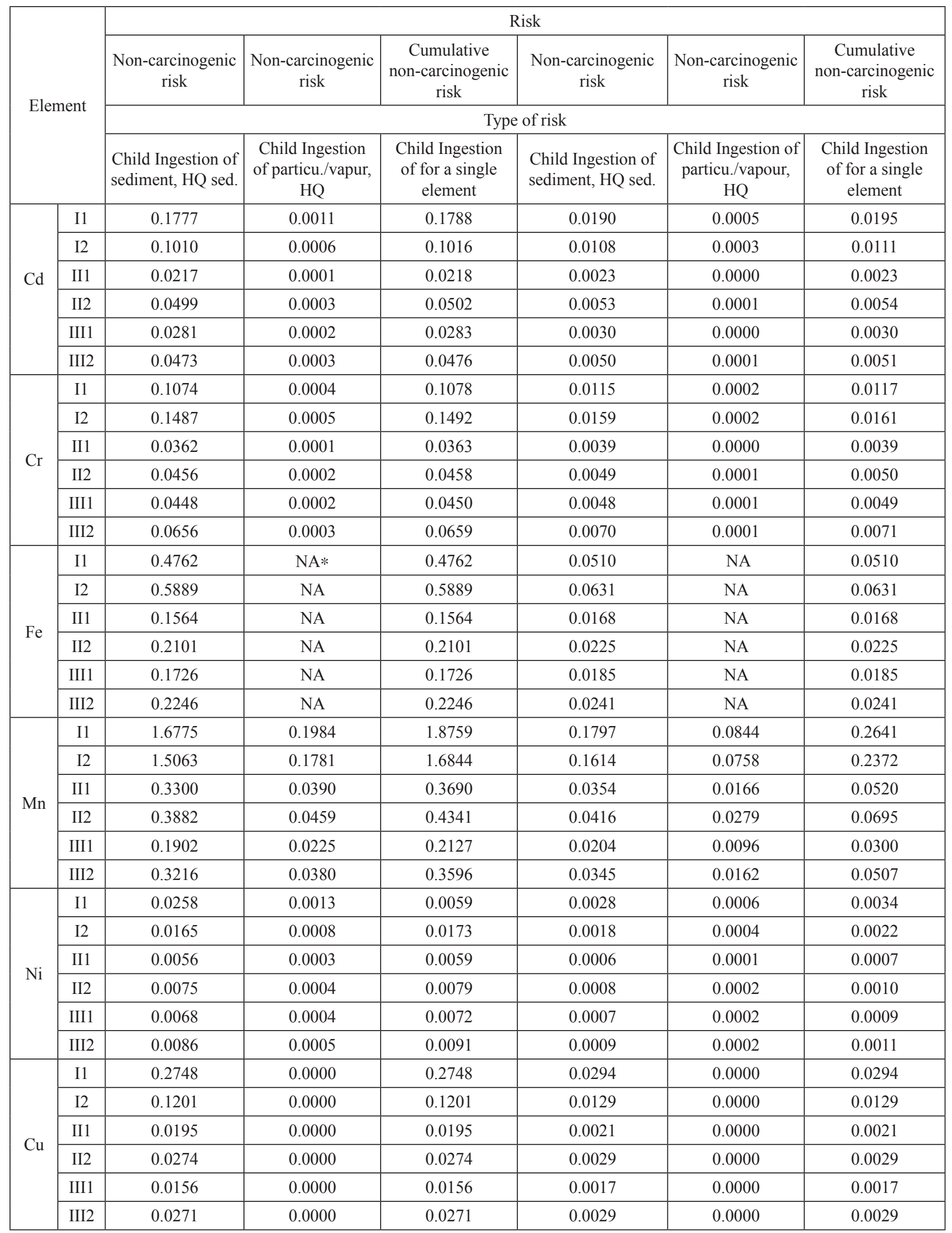


Table 3. Continued.

\begin{tabular}{|c|c|c|c|c|c|c|c|}
\hline \multirow{5}{*}{$\mathrm{Pb}$} & I1 & 15.8534 & NA & 15.8534 & 1.6987 & NA & 1.6987 \\
\cline { 2 - 8 } & I2 & 27.8381 & NA & 27.8381 & 2.9826 & NA & 2.9826 \\
\cline { 2 - 8 } & II1 & 2.2710 & NA & 2.2710 & 0.2433 & NA & 0.2433 \\
\cline { 2 - 8 } & II 2 & 3.1520 & NA & 3.1520 & 0.3377 & NA & 0.3377 \\
\cline { 2 - 8 } & III1 & 2.1801 & NA & 2.1801 & 0.2336 & NA & 0.2336 \\
\cline { 2 - 8 } & III2 & 2.6279 & NA & 2.6279 & 0.2816 & NA & 0.2816 \\
\hline
\end{tabular}

Table 3. (extension)

\begin{tabular}{|c|c|c|c|c|c|c|c|}
\hline \multirow{6}{*}{$\mathrm{Hg}$} & I1 & 0.0026 & $\begin{array}{l}0.0000 \\
0.0137\end{array}$ & 0.0163 & 0.0003 & $\begin{array}{l}0.0000 \\
0.0059\end{array}$ & 0.0062 \\
\hline & I2 & 0.0015 & $\begin{array}{l}0.0000 \\
0.0081\end{array}$ & 0.0096 & 0.0002 & $\begin{array}{l}0.0000 \\
0.0035\end{array}$ & 0.0037 \\
\hline & II1 & 0.0002 & $\begin{array}{l}0.0000 \\
0.0010\end{array}$ & 0.0012 & 0.0000 & $\begin{array}{l}0.0000 \\
0.0004\end{array}$ & 0.0004 \\
\hline & II2 & 0.0001 & $\begin{array}{l}0.0000 \\
0.0003\end{array}$ & 0.0004 & 0.0000 & $\begin{array}{l}0.0000 \\
0.0001\end{array}$ & 0.0001 \\
\hline & III1 & 0.0003 & $\begin{array}{l}0.0000 \\
0.0018\end{array}$ & 0.0021 & 0.0000 & $\begin{array}{l}0.0000 \\
0.0008\end{array}$ & 0.0008 \\
\hline & III2 & 0.0002 & $\begin{array}{l}0.0000 \\
0.0013 \\
\end{array}$ & 0.0015 & 0.0000 & $\begin{array}{l}0.0000 \\
0.0005 \\
\end{array}$ & 0.0005 \\
\hline \multirow{6}{*}{ As } & I1 & 0.0101 & NA & 0.0101 & 0.0011 & NA & 0.0011 \\
\hline & I2 & 0.0098 & NA & 0.0098 & 0.0010 & NA & 0.0010 \\
\hline & II1 & 0.0100 & NA & 0.0100 & 0.0011 & NA & 0.0011 \\
\hline & II2 & 0.0110 & NA & 0.0110 & 0.0012 & NA & 0.0012 \\
\hline & III1 & 0.0098 & NA & 0.0098 & 0.0010 & NA & 0.0010 \\
\hline & III2 & 0.0098 & NA & 0.0098 & 0.0010 & NA & 0.0010 \\
\hline \multirow{6}{*}{$\mathrm{Ba}$} & I1 & 0.0059 & 0.0001 & 0.0060 & 0.0006 & 0.0000 & 0.0006 \\
\hline & $\mathrm{I} 2$ & 0.0052 & 0.0001 & 0.0053 & 0.0005 & 0.0000 & 0.0005 \\
\hline & II1 & 0.0061 & 0.0001 & 0.0062 & 0.0006 & 0.0000 & 0.0006 \\
\hline & II2 & 0.0045 & 0.0001 & 0.0046 & 0.0005 & 0.0000 & 0.0005 \\
\hline & III1 & 0.0087 & 0.0002 & 0.0089 & 0.0009 & 0.0001 & 0.0010 \\
\hline & III2 & 0.0128 & 0.0002 & 0.0130 & 0.0014 & 0.0001 & 0.0015 \\
\hline \multicolumn{8}{|c|}{ Cumulative sediment risk for all elements - risk is additive } \\
\hline \multicolumn{2}{|c|}{ I1 } & 18.7433 & 0.2150 & 18.9583 & 2.0082 & 0.0916 & 2.0998 \\
\hline \multicolumn{2}{|c|}{$\mathrm{I} 2$} & 30.4168 & 0.1882 & 30.6050 & 3.2588 & 0.0802 & 3.3390 \\
\hline \multicolumn{2}{|c|}{ II1 } & 2.8767 & 0.0406 & 2.9173 & 0.3586 & 0.0171 & 0.3757 \\
\hline \multicolumn{2}{|c|}{ II 2} & 3.9364 & 0.0472 & 3.9836 & 0.4195 & 0.0284 & 0.4479 \\
\hline & & 2.6927 & 0.0253 & 2.7180 & 0.2873 & 0.0109 & 0.2982 \\
\hline & & 3.3854 & 0.0406 & 3.4260 & 0.3627 & 0.0172 & 0.3799 \\
\hline & & & & Carcino & & & \\
\hline & & Ingestion & nent partic & & n of sedi & irticulates & \\
\hline & $\mathrm{I} 1$ & & & & & & \\
\hline & $\mathrm{I} 2$ & & & & & & \\
\hline $\mathrm{Cd}$ & II1 & & & & & & \\
\hline $\mathrm{Cu}$ & II2 & & & & & & \\
\hline & III1 & & & & & & \\
\hline & III2 & & & & & & \\
\hline
\end{tabular}


Table 3. (extension)

\begin{tabular}{|c|c|c|c|}
\hline \multirow{6}{*}{$\mathrm{Cr}$} & $\mathrm{I} 1$ & & 0.1340 \\
\hline & $\mathrm{I} 2$ & & 0.1856 \\
\hline & II1 & & 0.0452 \\
\hline & II2 & & 0.0569 \\
\hline & III1 & & 0.0558 \\
\hline & III2 & & 0.0819 \\
\hline \multirow{6}{*}{$\mathrm{Ni}$} & I1 & & 0.0043 \\
\hline & $\mathrm{I} 2$ & & 0.0027 \\
\hline & II1 & & 0.0009 \\
\hline & II2 & & \\
\hline & III1 & & \\
\hline & III2 & & \\
\hline \multirow{6}{*}{ As } & $\mathrm{I} 1$ & 0.6023 & 0.0005 \\
\hline & $\mathrm{I} 2$ & 0.5786 & 0.0004 \\
\hline & II1 & 0.5915 & 0.0004 \\
\hline & II2 & 0.6518 & 0.0005 \\
\hline & III1 & 0.5813 & 0.0004 \\
\hline & III2 & 0.5793 & 0.0004 \\
\hline \multicolumn{4}{|c|}{ Cumulative carcinogenic risk } \\
\hline \multicolumn{2}{|c|}{ I1 } & 0.6023 & 0.1499 \\
\hline \multicolumn{2}{|c|}{$\mathrm{I} 2$} & 0.5786 & 0.1950 \\
\hline \multicolumn{2}{|c|}{ II1 } & 0.5915 & 0.0479 \\
\hline \multicolumn{2}{|c|}{ II2 } & 0.6518 & 0.0617 \\
\hline \multicolumn{2}{|c|}{ III1 } & 0.5813 & 0.0590 \\
\hline \multicolumn{2}{|c|}{ III2 } & 0.5793 & 0.0866 \\
\hline
\end{tabular}

treatment plant that discharges into the Korbevačka. This might be the reason for the variations of the metal cations concentrations between sampling sites $\mathrm{I}_{2}$ and $\mathrm{II}_{2}$ or from $\mathrm{I}_{3}$ to $\mathrm{II}_{3}$. The heavy metal speciation and solubility is affected by $\mathrm{pH}$ and redox potential in the river water and sediments. Although the concentrations of heavy metal cations in sediments were quite high due to neutral or slightly alkaline conditions in river water, the solubility of the mentioned heavy metal cations was partly prevented [26]. In case any current equilibrium condition $(\mathrm{pH}$, redox potential) changes, these sediments could become an additional source of metals for the Korbevačka [27]. Dominant heavy metal species in the Korbevačka river sediments do not need further comments, but additional argumentation is required in the case of Cr. Chromium (VI) is the form of $\mathrm{Cr}$ commonly found at contaminated sediments. As chromium can exist in chromium (III) form depending on $\mathrm{pH}$ and redox conditions, it is assumed that chromium (VI) in the Korbevačka sediments was the dominating chromium species due to aerobic conditions in sediments.

Following the toxicological profiles of all the investigated elements [28], it can be seen that most of the heavy metals have adverse health effects on humans, the so-called toxicological effects; but some of the metals are additionally carcinogenic.

By incorporating the obtained measured data (Table 1) into Equations (1)-(8), the following values were obtained: the non-carcinogenic hazard index and the carcinogenic lifetime risk for individual elements, the cumulative risk for different exposure pathways for individual elements, and the cumulative risk for all elements (Table 3).

The investigation shows that the measured sediment concentrations of all the investigated elements generate no significant carcinogenic lifetime risks due to ingestion and/or inhalation of sediment particulates. No matter how small the probability, a carcinogenic risk of ingestion and/or inhalation of sediment particulates exists and varies from the maximum value of $0.6023 \times 10^{-6}$ in the case of As to a minimum value of $0.5786 \times 10^{-6}$ for As ingestion, and the maximum value of $0.1836 \times 10^{-6}$ in the case of $\mathrm{Cr}(\mathrm{VI})$ to the minimum value of $0.0004 \times 10^{-6}$ for As inhalation of sediment particulates (Table 3). Hence, the risk that evolves due to exposure to heavy metal cations in sediments merely contributes to the total cancer risks that it are completely insignificant.

On the other hand, the non-carcinogenic risk, expressed as the hazard quotient, is not so benevolent. 
The hazard quotient is close to one or even exceeds that value, particularly in cases of the exposure of children (Table 3). Generally speaking, the hazard quotient for the ingestion and/or inhalation of sediment particulates by children is approximately 10 times greater in comparison to the corresponding results obtained for adults. In both cases (children and adults) the values of HQ corresponding to ingestion were higher than those corresponding to the inhalation of sediment particulates for all elements, except $\mathrm{Hg}$ (Table 3). Mercury is the only element for which inhalation of vapours seems to pose a higher risk, compared to ingestion due to the significant vapour pressure of $\mathrm{Hg}$ at ambient temperature. The HQ of heavy metals through ingestion and/or inhalation of sediment particulates decreases with increasing distance from the Grot Mine, which indicates that health risks diminish with distance from the mine. The differences in the total metal HQ for various locations along the Korbevačka are largely attributable to the significantly different contributions of $\mathrm{Pb}$ and $\mathrm{Mn}$.

There is a particular danger of contamination from separate heavy metals, from the point of view of HQ. The HQ values of $\mathrm{Cd}, \mathrm{Cr}, \mathrm{Ni}, \mathrm{Cu}, \mathrm{Ba}, \mathrm{Hg}, \mathrm{As}, \mathrm{Fe}$, and $\mathrm{Mn}$ (only for adult) for the ingestion and/or inhalation of sediment particulates by children and adults were generally less than 1, which indicates that the local inhabitants will not be exposed to a potential health risk by ingestion and/or inhalation of the sediment particulates. The present results indicate that $\mathrm{Pb}$ was the major component contributing to the potential health risk, with Mn (in the case of children's exposure) being of secondary importance. Based on the data obtained in this study, $\mathrm{Pb}$ and $\mathrm{Mn}$ pose a clear potential risk to the local inhabitants due to ingestion and/or inhalation of sediment particulates.

The heavy metals cumulative non-carcinogenic effect gives reasons for concern (Table 3), as the hazard index for the maximum content of the metals (location 1) was 30.6050 and 3.3390 for children and adults, respectively. This is an alarming value for toxicologists since it indicates that human health is endangered, but direct implications of cumulative effects of heavy metals in sediment and their influence on human health were not within the scope of this investigation.

As for cadmium, the renal no observed adverse effect level (NOAEL) for $\mathrm{Cd}$ is $0.0021 \mathrm{mg} / \mathrm{kg} \cdot$ day. MRL for $\mathrm{Cd}$ is $0.0002 \mathrm{mg} / \mathrm{kg} \cdot$ day (Table 2). Since the maximum calculated values of the non-carcinogenic $\mathrm{CDI}$ for $\mathrm{Cd}$ for child and adult ingestion of sediment particulates are $0.1777 \mathrm{mg} / \mathrm{kg} \cdot$ day and $0.0190 \mathrm{mg} / \mathrm{kg} \cdot$ day, respectively (location 1), it could be concluded that there is a potential non-carcinogenic risk that could eventually be caused by $\mathrm{Cd}$ for children and adults who are exposed to the sediment particulates of the Korbevačka River.

Chromium risk analysis predicts that the current occupational standards for hexavalent chromium permit a lifetime excess risk of dying of lung cancer that exceeds 1 in 10 for $\mathrm{Cr}$ concentrations in air of $1 \mathrm{mg} / \mathrm{m}^{3}$. The maximum calculated risk in the case of the Korbevačka sediments is very small $\left(0.1856 \times 10^{-6}\right.$, location 1$)$, hence there is no respective cancer risk. Corresponding toxicological effects can arise when daily intake is above the RfD of $\mathrm{Cr}$ or $0.003 \mathrm{mg} / \mathrm{kg} \cdot$ day. The present calculations for maximum concentration of $\mathrm{Cr}$ revealed that the daily intake is nowhere near the value of child non-carcinogenic CDI $(0.000446 \mathrm{mg} / \mathrm{kg} \cdot$ day, location 1$)$, hence a child noncarcinogenic hazard is not possible.

Iron is ubiquitous in biological systems. Iron is essential to all organisms, except for a few bacteria. It is mostly stably incorporated in the inside of metalloproteins, because it causes the production of free radicals that are generally toxic to cells in exposed or free form. Iron is necessary for good health - daily iron requirements are 8.7 and $6.7 \mathrm{mg}$ for males aged 1118 and 19+ years, respectively [29]. For women aged $11-50$ the estimated average daily iron requirement is $11.4 \mathrm{mg}$, while for postmenopausal (50+ years) women it is $6.7 \mathrm{mg}$. Estimated average daily requirements for children are $1.3 \mathrm{mg}$ (0-3 months), $3.3 \mathrm{mg}$ (4-6 months), $6.0 \mathrm{mg}$ (7-12 months), $5.3 \mathrm{mg}$ (1-3 years), $4.7 \mathrm{mg}$ (4-6 years), and $6.7 \mathrm{mg}$ (7-10 years). The present calculations for child and adult ingestion of sediment non-carcinogenic maximum CDIs for $\mathrm{Fe}(0.4122$ and $0.0442 \mathrm{mg} / \mathrm{kg} \cdot$ day, respectively, location 1) show that these concentrations of $\mathrm{Fe}$ do not exceed the chronic RfD (0.7 mg/kg·day, Table 2).

Manganese is one out of the three toxic essential trace elements, which means that it is not only necessary for humans to survive, but it is also toxic at high concentrations. The case of manganese is rather complex. The origin of manganese in the Korbevačka sediments is twofold. Manganese is a natural part of sediments but it is additionally brought there by wastewaters from Grot Mine and the flotation dump. It can bring forth a variety of serious toxic responses upon prolonged exposure to elevated concentrations, either orally or by inhalation. The present calculations for child and adult ingestion of sediment noncarcinogenic maximum CDIs for Mn (0.0772 and $0.0083 \mathrm{mg} / \mathrm{kg} /$ day, respectively, location 1) show that the concentration of $\mathrm{Mn}$ exceeds the chronic RfD for children $(0.046 \mathrm{mg} / \mathrm{kg} \cdot \mathrm{day}$, Table 1$)$. However, since the contribution of the mine to the Mn cations content in the Korbevačka River sediments is not negligible, further monitoring of Mn cations is necessary.

Nickel is an element that occurs in the environment at very low levels and is essential in small doses, but it can be dangerous when the maximum tolerable amounts are exceeded. Nickel is a probable human carcinogen as some industrial $\mathrm{Ni}$ compounds cause carcinogenic effects, although many others do not. The present results showed that the current concentrations of $\mathrm{Ni}$ cations in the Korbevačka River sediments are below any alerting values.

Copper is an essential micronutrient. Copper in the surface sediment, or aerated sediment, is usually present 
as $\mathrm{Cu}(\mathrm{II})$. Although most copper salts occur in two valence states, i.e., $\mathrm{Cu}(\mathrm{I})$ or $\mathrm{Cu}(\mathrm{II})$ ions, the biological availability and toxicity of copper is most likely associated with the divalent state [29]. Child and adult ingestions of sediment non-carcinogenic maximum CDIs for $\mathrm{Cu}(0.0110 \mathrm{mg} / \mathrm{kg} \cdot d a y$ and $0.0012 \mathrm{mg} / \mathrm{kg} \cdot \mathrm{day}$, respectively, location 1) are smaller than oral chronic RfD (0.04 mg/kg·day), hence copper generates risk neither for children nor for adults.

The presence of lead in the Korbevačka sediments is exclusively related to mining activities. Lead can affect almost every organ and system in the human body. The most serious source of exposure to soil lead is through direct ingestion (eating) of the contaminated soil or dust. Assuming the worst-case scenario, for children with daily sediment intake rates of $200 \mathrm{mg} /$ day and maximal concentration of $\mathrm{Pb}$ cations of $7620.7 \mathrm{mg} / \mathrm{kg}$ in the sediment, the calculated chronic daily intake for non-carcinogenic risk is $0.0974 \mathrm{mg} / \mathrm{kg} \cdot \mathrm{day}$, and if all that $\mathrm{Pb}$ would enter the blood, which is not the case, the child would have serious health problems.

Mercury is a toxic substance with no known function in human biochemistry or physiology and does not occur naturally in living organisms. The forms or species of mercury are usually classified into the general categories of organic and inorganic [29]. The redox potential and $\mathrm{pH}$ of the system determine the stable forms of $\mathrm{Hg}$ that will be present. Mercury is most toxic in its alkylated forms, which are soluble in water and volatile in air. The current concentrations of $\mathrm{Hg}$ cations in the Korbevačka River sediments are below any alerting values for human health.

Arsenic mobility, bioavailability, and toxicity are dependent on speciation: arsenite $\left(\mathrm{AsO}_{3}{ }^{3-}\right)$ forms are much more toxic to biological species and are more mobile than arsenate $\left(\mathrm{AsO}_{4}^{3-}\right)$ forms [29]. Metalloorganic forms of arsenic also may be much more bioavailable than inorganic forms. Under oxic conditions As (III) mobility is enhanced. Arsenic is apparently highly mobile in anoxic sediment-water systems. The calculated risk for the ingestion of sediment particulates is more than 100 times greater in comparison to the corresponding results obtained for the inhalation of sediment particulates. But there is no respective cancer risk in both cases. Corresponding toxicological effects can arise when daily intake is above the RfD of As or $0.0003 \mathrm{mg} / \mathrm{kg} \cdot$ day. The present calculations revealed that the maximum daily intake is nowhere near the value of child and adult non-carcinogenic CDI $\left(0.3310^{-5}\right.$ and $0.3510^{-6} \mathrm{mg} / \mathrm{kg} \cdot \mathrm{day}$, location 2$)$, hence human noncarcinogenic hazard is not possible.

Barium is a divalent alkaline-earth metal that has not been evaluated by the EPA for evidence of human carcinogenic potential [30]. The oral reference dose (RfD) of $\mathrm{Ba}$ is $0.07 \mathrm{mg} / \mathrm{kg} \cdot$ day [31-33]. Child and adult ingestion of sediment non-carcinogenic maximum CDIs for Ba $(0.0009 \mathrm{mg} / \mathrm{kg} \cdot d a y$ and $0.0001 \mathrm{mg} / \mathrm{kg} \cdot \mathrm{day}$, respectively, location 3 ) are much smaller then oral chronic RfD, hence barium generates risk neither for children nor for adults.

\section{Conclusions}

Metal-rich wastes resulting from the mining and flotation activities are one of the most important potential hazards to environmental quality [34-36]. Generally, soils and waters of mining areas show high contents of toxic metal cations as arsenic, lead, cadmium [37-39]. The results of heavy metal cations content in the Korbevačka sediments and health risk assessment obtained in this study confirm this fact.

This study points to a significant level of contamination of the Korbevačka sediments while the obtained results help expand our knowledge regarding the impact of mining and flotation operations on the environment and the potential risk to human health. The extent of the Korbevačka River sediments contamination by heavy metal cations decreases with increasing distance from the Grot Mine, which indicates that health risks diminish with distance from the mine.

The results of the risk assessment calculated for lifetime exposure indicate that the carcinogenic risk is completely insignificant and falls under the range of threshold values $\left(10^{-4}-10^{-6}\right)$, above which environmental and regulatory agencies consider the risk unacceptable. But the non-carcinogenic risk is significant, mainly for children, since it approaches values that could be unacceptable. The present results indicate that $\mathrm{Pb}$ is the major contributor to the potential non-carcinogenic risk to children and adults, with Mn (in the case of children's exposure) being of secondary importance.

Therefore, the area surrounding Grot Mine needs effective measures to reduce the toxic metal cations contamination. In general, exposure risk assessment of the present type can be used for screening purposes in order to identify important exposure pathways and to determine the urgency of sediment remediation actions.

\section{Acknowledgements}

The research was carried out in the framework of project No. III-43014 financed by the Ministry of Education, Science, and Technological Development of the Republic of Serbia.

\section{Conflict of Interest}

The authors declare no conflict of interest.

\section{References}

1. OGUNFOWOKAN A.O., OYEKUNLE J.A.O., OLUTONA G.O., ATOYEBI A.O., LAWAL, A. Speciation 
Study of Heavy Metals in Water and Sediments from Asunle River of the Obafemi Awolowo University, Ile-Ife, Nigeria, International Journal of Environmental Protection March., 3 (3), 6, 2013.

2. AYDINAL C., CRESSER M.S. Distribution of Heavy Metals in Irrigated Vertisol Profiles in Semiarid Region of Turkey, Polish J. of Environ. Stud. 18 (4), 539, 2009.

3. GROS M., PETROVIĆ M., GINEBREDA A., BARCELÓ D. Removal of pharmaceuticals during wastewater treatment and environmental risk assessment using hazard indexes, Environment International, 36 (1), 15, 2010.

4. TEKIN-ÖZAN S., KIR İ. Concentrations of Some Heavy Metals in Tench (Tinca tinca L., 1758), Its Endoparasite (Ligula intestinalis L., 1758), Sediment and Water in Beyşehir Lake, Turkey, Polish J. of Environ. Stud. 17 (4), 597, 2008.

5. HUA1 Z., YINGHUI J., TAO Y., MIN W., GUANGXUN S., MINGJUN D. Heavy Metal Concentrations and Risk Assessment of Sediments and Surface Water of the Gan River, China. Pol. J. Environ. Stud. 25 (4), 1529, 2016.

6. NOURI J., LORESTANI B., YOUSEFI N., KHORASANI N., HASANI A.H., SEIF S., CHERAGHI M. Phyto remediation potential of native plants grown in the vicinity of Ahangaran lead - zinc mine (Hamedan, Iran). Environ Earth Sci. 62 (3), 639, 2011.

7. VICENTE-MARTORELL J.J., GALINDO-RIANO M.D., GARCIA-VARGAS M., GRANADO-CASTRO M.D. Bioavailability of heavy metals monitoring water, sediments and fish species from a polluted estuary, Journal of Hazardous Materials, 162 (2-3), 823, 2009.

8. GEVORGYAN G.A., MAMYAN1 A.S., HAMBARYAN L.R., KHUDAVERDYAN S.Kh., VASEASHTA A. Environmental Risk Assessment of Heavy Metal Pollution in Armenian River Ecosystems: Case Study of Lake Sevan and Debed River Catchment Basins, Pol. J. Environ. Stud. 25 (6), 2387, 2016.

9. BAI J., CUI B., CHEN B., ZHANG K., DENG W., GAO H., XIAO R. Spatial distribution and ecological risk assessment of heavy metals in surface sediments from a typical plateau lake wetland, China, Ecological Modelling, 222 (2), 301, 2011.

10. LIU X., SONG Q., TANG Y., LI W., XU J., WU J., WANG F., BROOKES P.C. Human health risk assessment of heavy metals in soil-vegetable system: A multi-medium analysis, Science of The Total Environment, 463-464 (1), $530,2013$.

11. ZHENG N., LIU J., WANG Q., LIANG Z. Health risk assessment of heavy metal exposure to street dust in the zinc smelting district, Northeast of China, Science of The Total Environment, 408 (4), 726, 2010.

12. OLAWOYIN R., OYEWOLE S.A., GRAYSON R.L. Potential risk effect from elevated levels of soil heavy metals on human health in the Niger delta, Ecotoxicology and Environmental Safety, Science of The Total Environment, 85, 120, 2012.

13. LUO X.S., DING J., XU B., WANG Y.J., LI H.B., YU $\mathrm{S}$. Incorporating bioaccessibility into human health risk assessments of heavy metals in urban park soils, The Total Environment, 424_(1), 88, 2012.

14. DRIRA Z., SAHNOUN H., AYADI H. Spatial Distribution and Source Identification of Heavy Metals in Surface Waters of Three Coastal Areas of Tunisia, Pol. J. Environ. Stud. 26 (3), 1057, 2017.

15. CANADIAN COUNCIL OF MINISTERS OF THE ENVIRONMENT, Protocol for the Derivation of Canadian Sediment Quality Guidelines for the Protection of Aquatic
Life, CCME EPC-98E, http://ceqg-rcqe.ccme.ca/download/ en/226/, (accessed 03 December, 2017).

16. EEC, Council Directive 75/440/EEC of 16 June 1975 concerning the quality required of surface water intended for the abstraction of drinking water in the Member States, http://eur-lex.europa.eu/legal-content/en/ ALL/?uri=CELEX:31975L0440 (accessed 03 December, 2017).

17. DJORDJEVIĆ LJ., GRŽETIĆ I., CVETKOVIĆ O. Ecochemical status of the Korbevačka River in South-Eastern Serbia. Fresen. Environ. Bull. 16 (11a), 1412, 2007.

18. CHAKRAVARTY M., PATGIRI A.D. Metal pollution assessment in sediments of the Dikrong River, NE, India. J. Hum. Ecol. 27 (1), 63, 2009.

19. U.S. EPA. Guidance for Characterizing Background Chemicals in Soil at Superfund Sites. Office of Emergency and Remedial Response, Washington, DC. OSWER Directive 9285.7-41, 2001. (accessed 03 December, 2017).

20. U.S. EPA, RAIS. The Risk Assessment Information System, https://rais.ornl.gov/ (accessed 03 December, 2017).

21. U.S. EPA, IRIS. http://cfpub.epa.gov/ncea/iris/index.cfm 2007, (accessed 09 December, 2017).

22. ATSDR. U.S. Agencyfor Toxic Substances and Disease Registry., 2007; http://www.atsdr.cdc.gov/mrls/ (accessed 05 December, 2017).

23. U.S. EPA. Soil Screening Guidance: Technical Background Document, EPA/540/ R- 95/128. Office of Soild Waste and Emergency Response. U.S. EPA, Washington, D.C., 1996; http://www.epa.gov/superfund/resources/soil/toc.htm\#pl. (accessed 10 December, 2017).

24. U.S. EPA. Supplemental Guidance for Developing Soil Screening Levels for Super- fund Sites, OSWER 9355.424, Office of Solid Waste and Emergency Response, 2001, http://www.epa.gov/superfund/resources/soil/ssgmarchol. pdf (accessed 10 December, 2017).

25. CANADIAN COUNCIL OF MINISTERS OF THE ENVIROMENT, Canadian sediment quality Guidelines. ISQG. Interim fresh water sediment quality guidelines, Summary tables, 2002. https://www.elaw.org/system/files/ sediment_summary_table.pdf (accessed 10 December, 2017).

26. HÜBNER R., ASTIN B.K., HERBERT H.R.J. Comparison of sediment quality guidelines (SQGs) for the assessment of metal contamination in marine and estuarine environments, Journal of Environmental Monitoring, 4, 2009.

27. DJORDJEVIĆ LJ., ŽIVKOVIĆ N., ŽIVKOVIĆ LJ., DJORDJEVIĆ A. Assessment of heavy metals pollution in sediments of the Korbevačka River south-eastern Serbia. Soil Sediment Contam., 21 (7), 889, 2012.

28. ATSDR Pb. U.S. Agency for Toxic Substances and Disease Registry, 2007; http://www.atsdr. cdc.gov/toxprofiles/tp13. html (accessed 10 December, 2017).

29. U.S.EPA. IRIS. Health Risk Assessment for Barium, On line, (Verification date 6/21/90.) Office of Health and Environmental Assessment, Environmental Criteria and Assessment Office, Cincinnati, OH. Retrieved, 4 (5), 95, 1995.

30. U.S.EPA. Health Effects Assessment Summary Tables, Annual FY-95, Prepared by the Office of Health and Environmental Assessment, Environmental Criteria and Assessment Office, Cincinnati, $\mathrm{OH}$, for the Office of Emergency and Remedial Response, Washington D.C., 1995.

31. U.S.EPA. Risk Assessment Guidance for Superfund, Volume 1, Human Health Evaluation Manual Part D, 
Standardized Planning, Reporting, and Review of Superfund Risk Assessments, Office of Solid Waste and Emergency Response, OSWER 9285.7-47, December, 2001.

32. U.S.EPA. Risk Assessment Guidance for Superfund, Volume 1, Human Health Evaluation Manual (Part E, Supplemental Guidance for Dermal Risk Assessment) Interim, OSWER 9285.7-02EP, July, 2004.

33. U.S.EPA. Risk Assessment Guidance for Superfund Volume I: Human Health Evaluation Manual (Part F, Supplemental Guidance for Inhalation Risk Assessment), Final, EPA-540-R-070-002, OSWER 9285.7-82, Office of Superfund Remediation and Technology Innovation, January, 2009.

34. ILUȚIU-VARVARA D. A. Researching the Hazardous Potential of Metallurgical Solid Wastes, Pol. J. Environ. Stud. 25 (1), 147, 2016.

35. LOU S., LIU1 S., DAI C., TAO A., TAN B., MA G., CHALOV R.S., CHALOV S.R. Heavy Metal Distribution and Groundwater Quality Assessment for a Coastal Area on a Chinese Island, Pol. J. Environ. Stud. 26 (2), 733, 2017.
36. ZHENXING W., LIYUAN C., ZHIHUI Y., YUNYAN W., HAIYING W. Identifying Sources and Assessing Potential Risk of Heavy Metals in Soils from Direct Exposure to Children in a Mine-Impacted City, Changsha, China, Journal of Environmental Quality Abstract - Heavy Metals in the Environment, 39 (5), 1616, 2010.

37. ABDULHAY H.S., RATHI M.H. Lead, Cadmium and Nickel Contamination of Roadside Soils and Plant Leaves in Baghdad City, Journal of Chemical and Pharmaceutical Research, 9 (8), 47, 2017.

38. PHAN K., STHIANNOPKAO S., KIM K.W., WONG M.H., SAO V., HASHIM J.H., MOHAMED YASIN M.S., ALJUNID S.M. Health risk assessment of inorganic arsenic intake of Cambodia residents through groundwater drinking pathway, Water Research, 44 (19), 5777, 2010.

39. LI S., ZHANG Q. Risk assessment and seasonal variations of dissolved trace elements and heavy metals in the Upper Han River, China, Journal of Hazardous Materials, 181 (1-3), 1051, 2010. 